\title{
Effect of Potassium Fertilizer on Development of Bacterial Blight of Rice
}

\author{
N. Begum ${ }^{\text {a }}$ M. M. Rahman ${ }^{\text {b }}$ M. A. Basharc, M. A. Hossain ${ }^{d}$ and M. N. Uddin ${ }^{\mathrm{e}}$ \\ ${ }^{a}$ BCSIR Laboratories, Dhaka, ${ }^{b}$ Institute of Fuel Research and Development(IFRD), ' Department of Botany, \\ University of Dhaka, ${ }^{d}$ Bangladesh Rice Research Institute(BRRI), Gazipur, and Planning and Development \\ Division(P\&D), BCSIR, Dr. Qudrat-I-Khuda Road, Dhanmondi, Dhaka-1205, Bangladesh.
}

\begin{abstract}
Effect of five potassium doses viz, recommended dose (RD) (40 kg Murate of Potash(MP)/hector), RD + $10 \mathrm{~kg} \mathrm{MP/ha,} \mathrm{RD} \mathrm{+} 20 \mathrm{~kg} \mathrm{MP} / \mathrm{ha}$, $\mathrm{RD}+30 \mathrm{~kg} \mathrm{MP} / \mathrm{ha}, \mathrm{RD}+40 \mathrm{~kg} \mathrm{MP} / \mathrm{ha}$ to manage bacterial blight of rice were studied during Boro season in 2005 . The experiment was laid in Randomized Completely Block Design (RCBD) having three replications. Highest disease severity (55.92\%) was observed due to bacterial leaf blight at maximum tillering stage when applied $30 \mathrm{~kg} \mathrm{MP} /$ ha additional potash. Lowest disease severity ( $0.45 \%)$ of bacterial leaf blight were recorded from the plot where no additional MP was applied but highest yield (4.35 tones/ha) was observed in the plot where additional $20 \mathrm{~kg} \mathrm{MP} / \mathrm{ha}$ was applied. The amount of potassium in the leaves did not vary significantly even after additional application of potassium either 30 or $20 \mathrm{~kg} \mathrm{MP} /$ ha though it was more $(1.31 \%)$ when applied $40 \mathrm{~kg} \mathrm{MP} / \mathrm{ha}$. In another experiment in the present study the lowest disease severity $15.22 \%$ and $10.53 \%$ were recorded when additional $5 \mathrm{~kg}$ MP /ha was applied seven days before inoculation at active tillering and panicle initiation stages, respectively. Disease severity was lower in single inoculation compare to multiple inoculations except the plot where $5 \mathrm{~kg} /$ ha additional potash applied three days before bacterial inoculation. Maximum yield (3.86, 4.38, 4.64 t/ha) was recorded when inoculated at active tillering, panicle initiation and flowering stages separately if potassium was applied seven days before inoculation than those of multiple inoculations. The results suggested that potassium top dressing just before disease initiation was good for higher yield and less disease development. However inoculation in all the growth stages of the crop gave lower yields even potassium application was done at seven or three days before or after inoculation.
\end{abstract}

Key words: Bacterial leaf blight, Oryza sativa L., Potassium fertilizer

\section{Introduction}

Rice (Oryza sativa L.) is one of the most important cereal crops of the world and more than $60 \%$ of the world population depends on rice for their carbohydrate in diet (FAO 2000). In respect of total cropped area and production, rice ranks the top position by covering about 10.80 million hectares of land from which 26.53 million tons of rice is produced per annum in Bangladesh (BBS, 2006). Rice constitutes about $92 \%$ of the total food grains produced and about $80 \%$ of the total cropped area of the country. It provides about $75 \%$ calorie and $55 \%$ protein intake in daily diet of the people (Siddique, 2002). Among the many causes of low yield of rice in Bangladesh, diseases and pests play a major role, sometimes leading to disastrous consequences (Fakir, 1982). Ironically, the tropical and subtropical climates that favour the production of rice is also favourable for its disease development. Out of 32 diseases of rice 10 are considered as major diseases among which bacterial leaf blight (BLB) caused by Xanthomonas oryzae pv. oryzae (Xoo) may cause substantial loss to rice both in quality and quantity in Bangladesh. BLB of rice is also a destructive disease in South and Southeast Asia. It is a systemic disease and may cause an average of $20-30 \%$ yield loss (Ou, 1985). In the tropics, depending on the severity of infection, the loss may be as high as 60-70\% (Ou, 1973 ). Srivasta and Kapoor (1989) obtained 6-37\% yield loss against 1-9 infection grade in India. The yield loss caused by BLB in Bangladesh has been estimated as 10-30\% (Ashrafuzzaman, 1992). Use of fertilizer use, and its judicious and timely application are important factor for yield maximization of modern rice (Ali, 1985). This dangerous and common disease of rice is being

\footnotetext{
* Corresponding author: E-mail: m2nashir@yahoo.com
} 
controlled specially by spraying bactericides in the field as well as by treating seeds with the seed treating chemicals and developing disease resistant cultivars. Use of chemicals for spraying in the field or treating seeds are creating environmental pollution. Nutritional management of the diseases could be considered as an alternate to chemicals and less hazardous to nature. Application of fertilizers and manures in the soil are aimed to supply nutrient elements to the plant that creates positive reaction, means of inducing disease resistance to plants and as a result the plants may recover the disease or may overcome the disease epidemic (Hossain et al., 1995 and Kundu et al., 1996). In general, plants receiving a balanced nutrition, in which all required elements are supplied in appropriate amounts, are more capable of protecting themselves from new infections and limiting existing infections than when one or more nutrients are supplied in excessive or deficient amounts. However, even a balanced nutrition may affect the development of a disease when the concentration of all the nutrients is increased or decreased beyond a certain range (Agrios, 1997).

Soil is a harbour of plants having complex system of nutrient elements. It is considered as principal supplier of plant nutrients. In Bangladesh, nutrient content in soil are becoming more and more unbalanced due to variation in their inherent capacities to supply them which gradually decline over time due to intensive cropping with high yielding varieties, application of limited number of nutrients, very little or no use of organic materials and improper soil and crop management practices (BARC, 1997). As a result, the cultivated crop plants are subjected to inadequate supply of nutrients of which is reflected to make them vulnerable to a particular pathogen and to develop acute or chronic symptoms resulted in poor yield and quality of harvest. In order to obtain the maximum yield by minimizing diseases, there is a need to add nutrients to the soil in a judicious way. Therefore, the present study was undertaken to determine the effect of potassium on the incidence and percent leaf area infection of BLB of rice caused by Xoo.

\section{Materials and Methods}

The experiment was carried out in the field of Plant Pathology Division, Bangladesh Rice Research Institute (BRRI), Gazipur during the transplanted Boro season i,e from December 2004 to May 2005.A modern transplanted Boro rice variety BRRIdhan 29 was used in this experiment.
The experimental period was December 2004 to May 2005. Seedlings were raised in the seed-bed during the month of December, 2004 and transplanted in the month of January, 2005. Experimental data were collected during the crop growing period, (March-May, 2005). The crops were harvested in May 2005.

\section{Seed bed preparation and raising of seedlings}

A small piece $(2 \mathrm{~m} \times 3 \mathrm{~m}$ ) of medium low field of BRRI farm was puddled with the power tiller. The land was marshy and rich in organic matter and no fertilizers were applied to the seedbed. Seeds were collected from the Plant Pathology Division, BRRI, Gazipur. Clean mature and healthy seeds were soaked in tap water for 24 hours. Sprouted seeds were sown uniformly in seedbed on December 2004. The seedbed was protected from birds and animals. Adequate water was applied to the growing seedlings in seedbed as and when required till before transplanting. The seed were then incubated in wet sack for 3 days for germination in room temperature.

\section{Experimental design and field layout}

The experiment was laid out in a Randomized Complete Block Design (RCBD) having three replications for each treatment. Distance between the blocks and between the plots was $50 \mathrm{~cm}$ and $25 \mathrm{~cm}$, respectively. There were altogether 15 (Expt.1) and 96 (Expt.2, 3, 4 and 5) plots for the study. Different treatments were assigned randomly to the unit plot $(2 \mathrm{~m} \times 1.5 \mathrm{~m})$. Details of the field layout are presented in the following/Next page.

\section{Land preparation}

The main land was opened by power tiller. Later the soils was paddled thoroughly by 3 successive laddering and harrowing. The field layout was made immediately after final land preparation in accordance with the experimental design. The individual plots of each unit plot was then raised so that the fertilizer could not move from one plot to other.

\section{Fertilizer application}

The following chemical fertilizers as per recommendation dose (RD) were applied in the field as a general dose: (1) Nitrogen (N) as urea $80 \mathrm{~kg} / \mathrm{ha},(2)$ Phosphorus $\left(\mathrm{P}_{2} \mathrm{O}_{5}\right)$ as TSP $60 \mathrm{~kg} / \mathrm{ha}$, (3) Potassium $\left(\mathrm{K}_{2} \mathrm{O}\right)$ as MP $40 \mathrm{~kg} / \mathrm{ha}$. One third of nitrogen $(\mathrm{N})$ and all other fertilizers were incorporated with 
soil during final land preparation. Rest $2 / 3$ rd of nitrogen were top dressed at 2 equal splits, $1 / 3 \mathrm{rd}$ at 25 days after transplanting and rest $1 / 3 \mathrm{rd}$ at maximum tillering stage. Additional potash (MP) was applied at 7 days before inoculation at the rate of $0\left(\mathrm{~T}_{1} /\right.$ control $), 10\left(\mathrm{~T}_{2}\right), 20\left(\mathrm{~T}_{3}\right), 30\left(\mathrm{~T}_{4}\right)$ and $40\left(\mathrm{~T}_{5}\right) \mathrm{kg} / \mathrm{ha}$ (Expt.1). Additional potash (MP) $(5 \mathrm{~kg} / \mathrm{ha})$ was applied at different growth stages (Active tillering, panicle initiation and flowering stage) at 7 days and 3 days before inoculation of Xoo (Expt. 2 and 3) and 3 and 7 days after inoculation (Expt. 4 and 5).

\section{Transplantation of seedlings}

Forty one day old seedlings were transplant the main field. Three seedlings per hill were planted with a spacing of 20 $\mathrm{cm} \times 20 \mathrm{~cm}$. Some of the seedlings were planted around the experimental plot as border crop at the same time. Transplantation was done on the 18th January, 2005.

\section{Isolation and purification of Xoo}

Bacterial blight infected leaves of rice were collected from the field of BRRI, Gazipur and brought to the laboratory of Plant Pathology Department of Botany, Dhaka University, Dhaka. The leaf tissue from the advancing lesion was used for isolation. The leaf tissue from advancing lesion were cut into pieces (ca $1.0 \mathrm{~mm}^{2}$ ). Surface sterilization was done by soaking the leaf pieces in $70 \%$ ethyl alcohol followed by dipping in 5\% chlorox for one minute (Vera cruz 1984). The surface sterilized pieces were kept for 30 minutes in sterile water to release the bacterium. Finally a full loop of the suspension was streaked on a plate of PSA medium and incubated at $28 \pm 2{ }^{\circ} \mathrm{C}$ temperature. Observation was made after 72 hours of streaking for the appearances of Xоo colonies. After 5 days the bright yellow bigger and slimy colonies were selected. The selected colonies were-re-streaked on the PSA medium. Finally pure single colonies were selected. The pure culture was used for further application. All these operation were done aseptically in the laminar flow chamber. The pure culture was preserved at refrigerator for further study.

\section{Preparation of culture and inoculation}

A bacterial leaf blight isolate $\left(\mathrm{Bx} 0^{9}\right)$ was tested for its pathogenicity. The isolates revived in PSA medium after shortterm preservation in a refrigerator just after isolation. The bacterium was grown on PSA slant for 48 hours. Then $10 \mathrm{ml}$ of sterile water was poured in the tubes. After 5 minutes, the cultures were scarped and transferred to sterile empty test tubes. Finally a bacterial suspension having approx $10^{8-10}$ $\mathrm{cfu} / \mathrm{ml}$ of water was made. The sterilized scissors were soaked in the suspension after cutting of each 3 leaves.

\section{Selection of pathogenic strains}

Fifteen days after inoculation, the isolates that developed blighted symptom were selected for resolution and further studies.

\section{Methods of inoculation}

The sterilized pair of scissors was soaked frequently in the suspension after cutting every 3-4 leaves. The plants were inoculated in the following manner:

\section{a) Experiment-1}

$\mathrm{T}_{1}=$ Recommendation dose (RD) $40 \mathrm{~kg} / \mathrm{ha}$ potash and no inoculation, $\mathrm{T}_{2}=\mathrm{RD}+$ additional $10 \mathrm{~kg}$ potash $/$ hectare and $100 \%$ inoculation, $\mathrm{T}_{3}=\mathrm{RD}+$ additional $20 \mathrm{~kg}$ potash/hectare and $100 \%$ inoculation, $\mathrm{T}_{4}=\mathrm{RD}+$ additional $30 \mathrm{~kg}$ potash $/$ hectare and $100 \%$ inoculation, $\mathrm{T}_{5}=\mathrm{RD}+$ additional $40 \mathrm{~kg}$ potash $/$ hectare and $100 \%$ inoculation.

\section{b) Experiment-2, 3, 4, 5}

$\mathrm{T}_{1}=$ Recommendation dose $(\mathrm{RD})$ and no inoculation, $\mathrm{T}_{2}=$ $\mathrm{RD}+$ additional $5 \mathrm{~kg} / \mathrm{ha}$ at ATS stage, $\mathrm{T}_{3}=\mathrm{RD}+$ additional $5 \mathrm{~kg} / \mathrm{ha}$ at PI stage, $\mathrm{T}_{4}=\mathrm{RD}+$ additional $5 \mathrm{~kg} / \mathrm{ha}$ at $\mathrm{FG}$ stage, $\mathrm{T}_{5}=\mathrm{RD}+$ additional $5 \mathrm{~kg} / \mathrm{ha}$ at ATS $+\mathrm{PI}$ stage, $\mathrm{T}_{6}=$ $\mathrm{RD}+$ additional $5 \mathrm{~kg} / \mathrm{ha}$ at ATS $+\mathrm{FG}$ stage, $\mathrm{T}_{7}=\mathrm{RD}+$ additional $5 \mathrm{~kg} / \mathrm{ha}$ at $\mathrm{PI}+\mathrm{FG}$ stage, $\mathrm{T}_{8}=\mathrm{RD}+$ additional $5 \mathrm{~kg} / \mathrm{ha}$ at ATS + PI+ FG stage.

\section{Assessment of severity of bacterial leaf blight}

Each plot was visited for recording the incidence and \% leaf area infection owing to bacterial leaf blight after 14 days of inoculation. Data were recorded visually by observing the symptoms. Ten hills were selected randomly from each plot. The parameters considered for this study were: (i) Total number of tillers per hill, (ii) Diseased tillers per hill, (iii) Total number of leaves per hill, (iv) Diseased leaves per hill, and (v) Percentage of diseased leaf area.

Disease incidence and percentage of diseased leaf area were calculated by the following formula:

Disease incidence, $(\mathrm{DI})=\frac{\text { Number of infected plants }}{\text { Total Number of plants }} \times 100$ 
$\%$ Leaf area diseased was assessed by the following formula.

$\%$ Leaf area diseased $=\frac{\text { Leaf area diseased }}{\text { Total leaf area }} \times 100$

The collected data were analyzed statistically and the mean, standard deviation and other calculations are evaluated considering 5\% level of significance by a computer package programme called SPSS (Statistical Package for Social Science) of version 14, now frequently being used to analyze all sort of data and this version was developed by SPSS Inc.

\section{Results and Discussion}

Effect of different doses of potassium at Xoo inoculation on disease severity (DS), grain weight and yield of rice

Effect of different doses of potassium at 7 days before Xoo inoculation on the disease severity, grain weight and yield of rice is presented in Table I. There were no significant differences in 1000 grain weight and yield among the treatments. However, significant difference were recorded in percent diseased leaf area/disease severity. The highest disease severity (55.92) was observed in $T_{4}$ and lowest (0.45) in $T_{1}$. However, additional $20 \mathrm{~kg} / \mathrm{ha}$ potassium (K) application was found more effective and economic. severity was lower in single inoculations $\left(\mathrm{T}_{2}, \mathrm{~T}_{3}\right.$, and $\left.\mathrm{T}_{4}\right)$ compare to multiple inoculations $\left(\mathrm{T}_{5}, \mathrm{~T}_{6}, \mathrm{~T}_{7}\right.$ and $\left.\mathrm{T}_{8}\right)$ except when $\mathrm{K}$ applied 3 days before bacterial inoculation. Disease severity was statistically similar $T_{2}(15.22 \%)$ with $T_{3}$ $(10.53 \%)$ and 14 treatments when potassium applied at 7 days before inoculation. However, 1000 grain weight were not significantly different among the treatments. Yield was higher in single inoculated plots at different growth stages eg. $\mathrm{T}_{2}, \mathrm{~T}_{3}$, and $\mathrm{T}_{4}(3.86,4.38,4.64 \mathrm{t} /$ ha respectively) when $\mathrm{K}$ applied at 7 days before inoculation compare to those of other applications. Yield of $\mathrm{T}_{5}, \mathrm{~T}_{6}, \mathrm{~T}_{7}$ and $\mathrm{T}_{8}(3.92,3.7,4.03$ and $3.48 \mathrm{t} /$ ha respectively) was higher when potassium applied at 3 days before inoculation compare to those of other applications. From the experiment, it might be concluded that $\mathrm{k}$ top dressing just before disease initiation was good for higher yield and less disease development. However, inoculation at all the growth stages of the crop gave lower yield even potassium application was done at 7 or 3 days before or after.

\section{Effect of different doses of potassium on rice grain}

Effect of different doses of potassium on rice grain are presented in Table III. The number of grains per panicle obtained in plants infected with bacterial leaf blight pathogens ranged from 73 to 80 . The highest number (80) of

Table I: Effect of different doses of potassium on the disease severity (DS ), grain weight and yield of rice

\begin{tabular}{l|c|c|c|c}
\hline Treatments & Disease severity & Grain weight $(\mathrm{g})$ & Yield(t/ha) & \% of potassium at harvesting \\
\hline $\mathrm{T}_{1}$ & $0.45 \mathrm{a}$ & 23.05 & 4.30 & $1.10 \mathrm{ab}$ \\
$\mathrm{T}_{2}$ & $29.49 \mathrm{ab}$ & 22.55 & 4.22 & $1.03 \mathrm{a}$ \\
$\mathrm{T}_{3}$ & $25.07 \mathrm{ab}$ & 21.77 & 4.35 & $1.14 \mathrm{ab}$ \\
$\mathrm{T}_{4}$ & $55.92 \mathrm{c}$ & 22.71 & 4.07 & $1.16 \mathrm{ab}$ \\
$\mathrm{T}_{5}$ & $21.13 \mathrm{ab}$ & 22.41 & 4.26 & $1.31 \mathrm{abc}$ \\
\hline LSD (5\%) & 53.37 & 0.45 & 1.87 & 0.26 \\
\hline
\end{tabular}

$\mathrm{T}_{1}=0$ ( control), $\mathrm{T}_{2}=10 \mathrm{~kg} / \mathrm{ha}, \mathrm{T}_{3}=20 \mathrm{~kg} / \mathrm{ha}, \mathrm{T}_{4}=30 \mathrm{~kg} / \mathrm{ha}$ and $\mathrm{T}_{5}=40 \mathrm{~kg} / \mathrm{ha}$, In column, values having common letter(s) do not differ significantly at $\mathrm{P}=0.05$ level by Duncan Multiple Rank Test (DMRT). Least Significant Difference (LSD) at 5\% level of significance were calculated here.

Effect of additional potassium (5 kg/ha) application at different growth stage on the disease severity, grain weight and yield.

Effect of additional potassium ( $5 \mathrm{~kg} / \mathrm{ha}$ ) application at different growth stage on the disease severity (DS), grain weight and yield of rice presented in Table II, III, IV and V. Disease grains per panicle was observed in $T_{2}(80)$ followed by $T_{5}$ (76.02) with significant difference with each other. In contrast, the lowest number of grains per panicle was observed in $T_{1}(73)$, followed by $T_{3}(74.36)$.

The highest number of healthy grains/panicle (72.0) was observed in $\mathrm{T}_{2}$ followed by $\mathrm{T}_{5}(71.18)$. These two treatments 
Table II: Effect of additional potassium application at 7 days before $X o o$ inoculation on disease severity, grain weight and yield of rice

\begin{tabular}{|c|c|c|c|}
\hline Treatments & Disease severity & Grain weight(g) & Yield ( $\mathrm{t} / \mathrm{ha}$ ) \\
\hline$\overline{\mathrm{T}_{1}}$ & $1.5 \mathrm{a}$ & 21.87 & $4.48 \mathrm{ab}$ \\
\hline $\mathrm{T}_{2}$ & $15.22 \mathrm{~b}$ & 22.82 & 3.86 bcde \\
\hline $\mathrm{T}_{3}$ & $10.53 \mathrm{~b}$ & 21.79 & $4.38 \mathrm{abc}$ \\
\hline $\mathrm{T}_{4}$ & $11.2 \mathrm{~b}$ & 22.39 & $4.64 \mathrm{a}$ \\
\hline $\mathrm{T}_{5}$ & $30.3 \mathrm{c}$ & 23.71 & 3.76 cde \\
\hline $\mathrm{T}_{6}$ & $38.91 \mathrm{~d}$ & 21.98 & $3.31 \mathrm{dc}$ \\
\hline $\mathrm{T}_{7}$ & $31.55 \mathrm{c}$ & 21.83 & $3.97 \mathrm{abcd}$ \\
\hline $\mathrm{T}_{8}$ & $32.19 \mathrm{~cd}$ & 21.37 & $3.26 \mathrm{e}$ \\
\hline $\operatorname{LSD}(p=0.05)$ & 6.99 & 2.68 & 0.68 \\
\hline
\end{tabular}

In column, values having common letter(s) do not differ significantly at $\mathrm{P}=0.05$ level by DMRT.

$\mathrm{T}_{1}=$ No inoculation, $\mathrm{T}_{2}=$ ATS, $\mathrm{T}_{3}=\mathrm{PI}, \mathrm{T}_{4}=\mathrm{FG}, \mathrm{T}_{5}=\mathrm{ATS}+\mathrm{PI}, \mathrm{T}_{6}=\mathrm{ATS}+\mathrm{FG}, \mathrm{T}_{7}=\mathrm{PI}+\mathrm{FG}, \mathrm{T}_{8}=\mathrm{ATS}+\mathrm{PI}+\mathrm{FG}$.

had however, significant difference with each other. On the other hand, the lowest number of healthy grains per panicle was observed in $\mathrm{T}_{1}(66.0)$.

Unfilled grains per panicle (\%) ranged from $6.37 \%$ to 10.3 $\%$. The highest number of unfilled grains per panicle was recorded on $\mathrm{T}_{2}$ treated plots $(10.3 \%)$ followed by $\mathrm{T}_{1}(9.6 \%)$. The lowest number of unfilled grains per panicle was observed in $\mathrm{T}_{5}(6.37 \%)$ followed by $\mathrm{T}_{3}(7.76 \%)$ and $\mathrm{T}_{4}$ $(7.82 \%)$.
Effect of additional potassium (K) application at 7 and 3 days after and before Xoo inoculation at different growth stages on rice grain.

The height number (127.70) of grains/panicle was observed in $\mathrm{T}_{4}$ at 7 days before Xoo inoculated plot. The lowest number (68.5) of grain/panicle was observed in $\mathrm{T}_{7}$ at 3 days after inoculation. Considering healthy grains/panicle the highest number (102.8) of healthy grains/panicle was observed in $\mathrm{T}_{4}$ at 7 days before inoculation. On the other hand the lowest

Table III: Effect of different doses of potassium on the grain quality of rice

\begin{tabular}{l|c|c|c|c}
\hline Treatments & $\begin{array}{c}\text { Total No. of } \\
\text { grains/panicle }\end{array}$ & $\begin{array}{c}\text { No. of healthy } \\
\text { grains/panicle }\end{array}$ & $\begin{array}{c}\text { Unfilled } \\
\text { grains/panicle (\%) }\end{array}$ & $\begin{array}{c}\text { Reduction of unfilled } \\
\text { grains/panicle }(\%)\end{array}$ \\
\hline $\mathrm{T}_{1}$ & $73.00 \mathrm{a}$ & $66.00 \mathrm{a}$ & $9.60 \mathrm{~b}$ & - \\
$\mathrm{T}_{2}$ & $80.00 \mathrm{a}$ & $72.00 \mathrm{c}$ & $10.00 \mathrm{bc}$ & 0.4 \\
$\mathrm{~T}_{3}$ & $74.36 \mathrm{a}$ & $68.59 \mathrm{ab}$ & $7.76 \mathrm{ab}$ & -1.84 \\
$\mathrm{~T}_{4}$ & $74.91 \mathrm{a}$ & $69.05 \mathrm{ab}$ & $6.82 \mathrm{ab}$ & -1.76 \\
$\mathrm{~T}_{5}$ & $76.02 \mathrm{a}$ & $71.18 \mathrm{bc}$ & 1.407 & -3.23 \\
\hline LSD $(0.05)$ & 7.171 & 3.156 & & \\
\hline
\end{tabular}

In column, values having common letter(s) do not differ significantly at $\mathrm{P}=0.05$

level by DMRT.

$\mathrm{T}_{1}=$ Recommended dose ( $40 \mathrm{~kg} /$ ha potassium) and $100 \%$ inoculation

$\mathrm{T}_{2}=\mathrm{RD}+$ additional $10 \mathrm{~kg}$ potassium /hectare and $100 \%$ inoculation .

$\mathrm{T}_{3}=\mathrm{RD}+$ additional $20 \mathrm{~kg}$ potassium /hectare and $100 \%$ inoculation

$\mathrm{T}_{4}=\mathrm{RD}+$ additional $30 \mathrm{~kg}$ potassium /hectare and $100 \%$ inoculation

$\mathrm{T}_{5}=\mathrm{RD}+$ additional $40 \mathrm{~kg}$ potassium /hectare and $100 \%$ inoculation 
number (59.1) grains/panicle observed in $\mathrm{T}_{7}$ at 3 days after inoculation.

Unfilled grains/panicle observed in $\mathrm{T}_{8}$ at 7 days before inoculation the lowest number $(8.30 \%)$ on unfilled grains/panicle observed in $T_{1}$. Control plot at 7 days after inoculation unfilled grains/panicle was higher in single inoculated plots at different growth stages eg. $\mathrm{T}_{2}, \mathrm{~T}_{3}$ and $\mathrm{T}_{4}(28.63,26.00$ and $27.56 \%$ respectively) when $\mathrm{K}$ applied at 7 days before inoculation compare to those of other application.
Average percentage disease severity of bacterial leaf blight on both inoculated and uninoculated plants answered at maximum tillering stage ranged from 0.45 to $55.92 \%$. It was observed the $\%$ disease severity was increasing trend with increased amount of $\mathrm{K}$. It indicated that potassium had no great preventive influence on disease severity of BLB in rice. This result contradicts with many workers (Reddy et al., 1979; Shahjahan, 1993; Haque, 1999). They reported that the percentage leaf area infection of BLB decreased with increased $\mathrm{K}$ fertilizers combination. Similar results was also

\section{Table IV: Effect of additional potassium application at 7 days before $X o o$ inoculation at different growth stages on} rice grain

\begin{tabular}{l|c|c|c|c}
\hline Treatments & $\begin{array}{c}\text { Total No. of } \\
\text { grains/panicle }\end{array}$ & $\begin{array}{c}\text { No. of healthy } \\
\text { grains/panicle }\end{array}$ & $\begin{array}{c}\text { Unfilled } \\
\text { grains/panicle (\%) }\end{array}$ & $\begin{array}{c}\text { Reduction of unfilled } \\
\text { grains/panicle }\end{array}$ \\
\hline $\mathrm{T}_{1}$ & $107.62 \mathrm{a}$ & $88.1 \mathrm{~cd}$ & $18.14 \mathrm{a}$ & 7.49 \\
$\mathrm{~T}_{2}$ & $108.97 \mathrm{a}$ & $81.04 \mathrm{~b}$ & $25.63 \mathrm{~cd}$ & 7.86 \\
$\mathrm{~T}_{3}$ & $118.84 \mathrm{~b}$ & $87.94 \mathrm{c}$ & $26.00 \mathrm{~cd}$ & 9.42 \\
$\mathrm{~T}_{4}$ & $127.70 \mathrm{c}$ & $92.5 \mathrm{~d}$ & $27.56 \mathrm{~d}$ & 6.01 \\
$\mathrm{~T}_{5}$ & $115.98 \mathrm{~b}$ & $87.93 \mathrm{c}$ & $24.15 \mathrm{bcd}$ & 3.82 \\
$\mathrm{~T}_{6}$ & $117.47 \mathrm{~b}$ & $91.67 \mathrm{~cd}$ & $21.96 \mathrm{~b}$ & 5.1 \\
$\mathrm{~T}_{7}$ & $113.93 \mathrm{~b}$ & $102.8 \mathrm{e}$ & $23.8 \mathrm{bc}$ & $21.05 \mathrm{e}$ \\
$\mathrm{T}_{8}$ & $115.13 \mathrm{~b}$ & $67.86 \mathrm{a}$ & 2.196 & 2.91 \\
\hline LSD $(0.05)$ & 4.918 & 4.314 & & \\
\hline
\end{tabular}

In column, values having common letter(s) do not differ significantly at $\mathrm{P}=0.05$ level by DMRT.

$\mathrm{T}_{1}=$ No inoculation, $\mathrm{T}_{2}=$ ATS, $\mathrm{T}_{3}=\mathrm{PI}, \mathrm{T}_{4}=\mathrm{FG}, \mathrm{T}_{5}=\mathrm{ATS}+\mathrm{PI}, \mathrm{T}_{6}=\mathrm{ATS}+\mathrm{FG}, \mathrm{T}_{7}=\mathrm{PI}+\mathrm{FG}$,

$\mathrm{T}_{8}=\mathrm{ATS}+\mathrm{PI}+\mathrm{FG}$

Different doses of additional potassium fertilizers were applied to know the effect of potassium on incidence and percentage of disease severity of BLB. In the present study, results revealed that the disease severity was increased with increasing amount of potassium applied. That means potassium had no strong preventive influence on bacterial leaf blight infection.

This result partially agree with many workers (Reddy et al., 1979; Naidu et al., 1978; Sudhakar et al., 1989). They reported that bacterial leaf blight of rice decreased with application of $\mathrm{k}$ fertilizers. Similar results were also reported by Shahjahan (1993) and Haque et al. (1999). It has been reported that phosphorous and potassium deficiencies incidence of BLB (Ou, 1985). In contrast, Rahman (2002) observed that increasing the doses of NPK fertilizers also increased the bacterial leaf blight. reported by Naidu et al. (1978) and Sudhakar et al. (1989). Anonymous, 1984 reported that balance fertilizer including potassium reduced percentage incidence of bacterial BLB in Nizersail.

Number of grains/panicle and unfilled grains/panicle differed significantly among the treatments. The lowest grains/panicle was observed in control and the lowest was observed in BLB inoculated plants. The nutrient uptake and translation inhibition in the infected plants resulted in the production of less number of filled grains/panicle with increased number of unfilled grains/panicle and finally the yield was drastically reduced (Rush and Lee, 1992).

Grain yield of rice profoundly varied from one treatment to another. Mean yield of different doses of BLB inoculated plots ranged from 4.07 to 4.35 tone/hector. The highest yield 
( $\mathrm{t} / \mathrm{ha}$ ) was obtained in $\mathrm{T}_{3}$ treated plot 10 hectors $20 \mathrm{~kg} / \mathrm{ha} \mathrm{K}$ application. The BLB inoculation affected plants by inhibiting nutrients and translocation of the nutrients in the severely infected plants of plant growth which resulted in the production of yield was reduced. Result also revealed that $\mathrm{k}$ had paritial inhibitory effect on BLB in rice. Because, in $\mathrm{T}_{4}$ disease severity (DS) was only $55.92 \%$. It was effect of additional $\mathrm{K}$ fertilization. Similar result was also observed in other additional $\mathrm{k}$ treated plots $\left(\mathrm{T}_{2}, \mathrm{~T}_{3}\right.$ and $\left.\mathrm{T}_{5}\right)$. These results were in agreement with the finding of Kozaka (1975) who reported that yield of rice was highest from NPK + cow dung application. Further Khairul Bashar (2000) reported that combined fertilizer including $\mathrm{K}$ and had inhibitory effect on BLB infection. Therefore, additional $\mathrm{K}$ application may be advisable to the farmers for managing BLB of rice which is ecologically friendly and economically viable. But further research work need to be carried out to confirm the results.

\section{References}

Agrios G. N. (1997). Plant Pathology. 4th Ed. Academic Press, New York and London, pp. 635-57.

Ali M. I. (1985). Nitrogen fertilizer efficiency in two major rice soils of Bangladesh. International Rice Research Note, Newslt, 10 (5): 23-24.

Arunyanart P., Surin A., Rojanahasadin W., Dhitikiattipong R. and Disthaporn S. (1984). Rice yield loss on Bacterial Leaf Blight (BLB). International Rice Research Note, Newslt, 9(6):10-25

Ashrafuzzaman H. (1992). Shasyer Rog (disease of crop). Forth reprint, published by Bangla Academy, Dhaka, Bangladesh, pp 203 -207.

BARC (1997). Fertilizer recommendation guide. Bangladesh Agricultural Research Council (BARC), pp 1-29.

BBS (2004). Bangladesh Bureau of Statistics, Ministry of Planning. Government of the Peoples' Republic of Bangladesh. Monthly Statistical Bulletin, November, pp 48-50.

Fakir G. A. (1982). An annotated list of seed borne diseases in Bangladesh Agricultural Information Service. Dhaka, Bangladesh pp 15-22.
FAO (2000). Production Year Book. Food and Agriculture Organization of the United Nations, Rome, Italy. 54: 77-78.

Haque M. A., Hossain A. and Hossain M. M. (1999). Effect of spacing and fertilizer on the incidence of bacterial leaf blight of rice. Bangladesh J. Agril. Res. 24 (1): 99105.

Hossain A., Yahia I.G. and Jahiruddin M. (1995). Effect of copper, boron and molybdenum on leaf spot disease and grain set of wheat. Bangladesh J. Training and Development 8(1 \& 2): 77-81.

Khairul Basher A. K. M. (2000). Effect of fertilizer and cow dung on sheath blight, bacterial leaf blight and yield of transplanted aman rice. M.S Thesis, pp. 50-59, Department of Plant Path. Bangladesh Agricultural University, Mymensingh, Bangladesh.

Kozaka T. (1975). Sheath blight in rice plants and its control. Rev. Plant Protect. Res. 8: 69-79

Kundu S., Hossain I. and Jahiruddin M. (1996). Effect of boron on leaf blotch (Bipolaris sorokiniana) and grain yield of wheat cv. Kanchan. Progress. Agric.7 (2): 171175 .

Naidu Trimurty V. D., Satpathy V. S.and Rao C. S. (1978). Effect of slow releasing fertilizers on the incidence of bacterial blight of rice. Cent. Rice res. Inst. Cuttack, India. 15(1):89-91.

Ou S. H. (1973). A hand book of rice in the topics, IRRI, Los. Banos, Laguna, Philippines. pp 5.

Ou S. H. (1985). Rice diseases. 2nd ed. CMI, Kew, Surrey, England, pp 38-50.

Rahman M. M. (2002). Effect top dressing of on different diseases of rice (BR 11), M.S. Thesis, pp 65-70, Department of Plant Path. Bangladesh Agricultural University, Mymensingh.

Rush M. C. and Lee F. N. (1992). Sheath blight In. Compendium of Rice Disease, eds. R.K. Webster and P.S. Gunnel. Aps Press. Minnesota, USA. pp 22-23. 
Shahjahan A. K. M. (1993). Practical approach to crop pest and disease management in Bangladesh. BARC, Farmgate, Dhaka-1215, Bangladesh. pp 31-168.

Siddique S. B. (2002). Rice Research in Bangladesh and future need. Paper presented at the 4th annual conference. Agriculturists forum of Bangladesh. pp 11-20.

Srivasta M. P. and Kapoor T. R. (1989). Yield loss due to bacterial leaf blight. Int. Rice Res. Newslt, 7 ( 3 ): 7-18.
Sudhakar R., Ramunujam K. and Ramabaran R. (1989). Effect of potassium level of Bacterial blight incidence and rice yield. Inter. Rice Res. Newslette 14(3): 36-43.

Vera Cruz C. M. (1984). Bacteriological and pathological variation of Xanthomonas camestris pv. Oryzae (Ishiyama 1922) Dye 1978, The pathogen of bacterial blight of rice. M. S. Thesis, University of the Philippines at Los Banos, Laguna, Philippines. pp151162.

Received : October 28, 2009;

Accepted : January 19, 2010 